\title{
Too soon and too late: the problem of archive work in Christian Petzold's Phoenix
}

Dora Osborne

\begin{tabular}{|l|l|}
\hline Date of deposit & 28022020 \\
\hline Document version & Author's accepted manuscript \\
\hline Access rights & $\begin{array}{l}\text { Copyright @ } 2020 \text { by New German Critique, Inc. This work has } \\
\text { been made available online in accordance with publisher policies } \\
\text { or with permission. Permission for further reuse of this content } \\
\text { should be sought from the publisher or the rights holder. This is } \\
\text { the author created accepted manuscript following peer review and } \\
\text { may differ slightly from the final published version. }\end{array}$ \\
\hline $\begin{array}{l}\text { Citation for } \\
\text { published version }\end{array}$ & $\begin{array}{l}\text { Osborne, DE 2020, 'Too soon and too late: the problem of archive } \\
\text { work in Christian Petzold's Phoenix', New German Critique, vol. } \\
\text { 47, no. 1 (139), pp. 173-195. }\end{array}$ \\
\hline $\begin{array}{l}\text { Link to published } \\
\text { version }\end{array}$ & \begin{tabular}{l} 
https://doi.org/10.1215/0094033X-7908434 \\
\hline
\end{tabular}
\end{tabular}

Full metadata for this item is available in St Andrews Research

Repository at: https://research-repository.st-andrews.ac.uk/ 


\title{
Too Soon and Too Late: The Problem of Archive Work in Christian Petzold's Phoenix
}

\begin{abstract}
Christian Petzold's Phoenix (2014) is set in the immediate aftermath of World War Two, but dedicated to Fritz Bauer, the man credited with initiating the Frankfurt Auschwitz Trials almost two decades later. In the light of other recent films about Bauer this article argues that Petzold's dedication indicates his interest in "archive work" as a fundamental task of "working through" the National Socialist past (performed emblematically by Bauer). It considers Petzold's return to Bauer's archive work in conjunction with his attempt to reconstruct an archive image for the film's opening, an attempt he went on to abandon. In the postwar world of Phoenix it is too soon to perform the reconstructive work undertaken by Bauer - here reconstruction has to do, rather, with erasure and forgetting. For contemporary memory work, meanwhile, all that remains are the material traces of the archive - Petzold must turn to this material, but sees that its (re)mediatization in mainstream Holocaust cinema has obscured its relationship to the traumatic events at stake. This article shows how Petzold uses his film to describe the difficulties of working with the archive from the positions of prematurity and belatedness, indicating as he does so how both the recuperative and the effacing work of postwar reconstruction inflect the material legacy available to subsequent generations.
\end{abstract}

Keywords: Petzold, Phoenix, Archive Work, Fritz Bauer, Reconstruction, Holocaust 


\section{Introduction}

Christian Petzold's 2014 film Phoenix is set in the aftermath of the Second World War, but concludes with a dedication to Fritz Bauer, the state prosecutor instrumental in bringing about the Frankfurt Auschwitz Trials that took place almost two decades later. Petzold's dedication is especially significant because it forms part of a recent wave of renewed interest in this pivotal figure of West Germany's history of "Aufarbeitung," that is, of "working through" its National Socialist past. ${ }^{1}$ Most notably, Fritz Bauer is the subject of no fewer than three recent German feature films: in Giulio Ricciarelli's Im Labyrinth des Schweigens (Labyrinth of Lies, 2014), Bauer encourages the fictional prosecutor, Johann Radmann, to pursue legal cases against Nazi criminals despite facing widespread resistance, and both Lars Kraume's Der Staat gegen Fritz Bauer (The People vs. Fritz Bauer, 2015) and the television production Die Akte General (The 'General' File, dir. Stephan Wagner, 2016) focus on Bauer's involvement in the arrest of Adolf Eichmann. Returning to the beginnings of "working through," or "Aufarbeitung," these three films reinforce how the process came to lay the foundations for what Aleida Assmann calls the "Aufbau," or "building up," of the Berlin Republic's commitment to remembering and commemorating the Holocaust. ${ }^{2}$ Furthermore, they show how "working through" the Nazi past is predicated on Bauer's work with archives, seen emblematically in the visual vocabulary of these films, which use the iconic repertoire of the archive - files and documents - as a key part of their mise-en-scène. With this trope they demonstrate how political power is inscribed in and through the archive. ${ }^{3}$ We see how Bauer's efforts contribute to making the still-political archive of the Nazi regime part of a

\footnotetext{
${ }^{1}$ Irmtrud Wojak published the first biography of Bauer in 2009 (Fritz Bauer 1903-1968. Eine Biografie) and Ronen Steinke's Fritz Bauer oder Auschwitz vor Gericht appeared four years later. Eichmanns Ende - Liebe, Verrat, Tod (2010, dir. Raymond Ley), a television docudrama, also featured Bauer and was broadcast the same year that Ilon Ziok's documentary film, Fritz Bauer. Tod auf Raten was released. 2014 also saw the opening of a travelling exhibition about Bauer at the Jewish Museum in Frankfurt ("Fritz Bauer. Der Staatsanwalt. NSVerbrechen vor Gericht").

2 Assmann, Das neue Unbehagen an der Erinnerungskultur, 59.

${ }^{3}$ Derrida, Archive Fever, 4.
} 
legal archive used in bringing perpetrators to justice, and they anticipate how this material will come to constitute a historical archive of National Socialism and the Holocaust. ${ }^{4}$ With their focus on the activation of archive material, these films introduce the idea of archive work as a prerequisite to the work of memory and mourning necessitated in the long process of "working through" the Nazi past.

These recent films about Fritz Bauer reflect, through the lens of historicized narrative, the important role archive work has had to play in "Aufarbeitung," not least in its legal and historiographical aspects. However, they also show how archive work returns and is pivotal to a later (contemporary) phase of Holocaust memory and memorialization. As those who lived through the events at stake are no longer here to recount their experiences, that is, as we enter the "postwitness era," we are increasingly reliant on material memory, specifically the documents, letters, and images (official and personal) that constitute the archive material of the period. ${ }^{5}$ This transition from the era of witnesses to the age of material memory is not unique to the Holocaust, indeed it is part of the shift from communicative to cultural memory that marks the loss of embodied memory. ${ }^{6}$ However, the archive that remains following the attempt to eradicate without trace is necessarily and fundamentally marked by the violence to which it bears witness. The archive after Auschwitz is, in the words of Georges DidiHuberman, an archive "in spite of all."" Moreover, the hyper-bureaucratized structures underpinning National Socialism made the archive fundamental to the administration of the regime; the return of the archive, and more recently, of archival tropes in subsequent attempts to work through and represent this trauma, is thus an uncanny phenomenon. ${ }^{8}$ The archive at

\footnotetext{
${ }^{4}$ According to Assmann, political archives are produced and used by the dominant power and lose significance once this power is lost. Political archives become significant again when reused as historical archives ("Canon and Archive," 102-03).

${ }^{5}$ See Diana Popescu and Tanja Schult, eds, Revisiting Holocaust Memory in the Post-Witness Era.

${ }^{6}$ See Assmann, Der lange Schatten der Vergangenheit, 54.

${ }^{7}$ Georges Didi-Huberman, Images in Spite of All.

${ }^{8}$ See, for example, Ernst van Alphen, who describes the "structural principles of the camps" as "archival" (Staging the Archive, 208), and Richard Crownshaw, who argues that "archival violence" is "contiguous from ghetto to museum" ("Reconsidering Postmemory," 227).
} 
stake in contemporary memory work might be understood as the post-Holocaust archive, a term that refers both to the material remains of attempted annihilation available to subsequent generations, and to the radically changed, complex, and complicated status of the archive after Auschwitz. ${ }^{9}$

The post-Holocaust archive aligns with and relates to other "posts," such as Marianne Hirsch's "postmemory," which, as Kirsten Gwyer, notes have been evoked in the discussion of Holocaust memory "after the end of living memory of this trauma" and which indicate how our understanding of this past is "determined precisely by our coming to it belatedly." 10 And like these other "posts," the post-Holocaust archive is characterized by the "practice of citation and supplementarity." 11 If, at the beginnings of "Aufarbeitung," archive work was a prerequisite of mourning and memory work, it has become critical to the perpetuation of memory culture in its late phase. Archive work returns after the work of mourning and memory, but, now, as we see in these films, it returns in narrative, aesthetic, and aestheticized mode. As such it indicates how the political and historical archives of National Socialism and the Holocaust have now become memorial archives that support the work of memory - in mediated form - after personal connection to the events at stake has been lost. Thus, the turn to the archive in contemporary memory culture is less about the production of historical knowledge than the attempted representation of traumatic memory. The archive is now a pivotal trope for the performative work of memorialization and commemoration, but asks ethical, aesthetic, and political questions of those who use it in this way. ${ }^{12}$

\footnotetext{
${ }^{9}$ These terms are fundamental to the argument made in my forthcoming monograph What Remains: The PostHolocaust Archive in German Memory Culture, which focuses on the relationship between contemporary Holocaust memory culture in Germany and the archive as seen in memorials, documentary film, and prose narratives.

${ }^{10}$ Kirsten Gwyer, "Beyond Lateness?” 137-38.

${ }^{11}$ Marianne Hirsch, The Generation of Postmemory, 5.

12 This article expands the argument made in the introduction of my book, where I also briefly discuss Fritz Bauer and Phoenix, to develop a sustained analysis of Petzold's film.
} 
Rather that reflecting on the "post-ness" of their engagement with the National Socialist past and early attempts at "Aufarbeitung," the films by Ricciarelli, Kraume, and Wagner view the past as distinct from the present. ${ }^{13}$ They tell the story of Bauer's archive work from the perspective of a "worked-through" past, which is to say, they seem to assume the completion of the task of "Aufarbeitung." In this way the films seem to perpetuate the kind of consensus around narratives of Germany's past that marks the mainstream cinema of the preceding two decades and which finds its "most prominent extension" in German heritage cinema. ${ }^{14}$ Given that Petzold's films, like the work of the Berlin School more broadly, resist this "cinema of consensus," 15 it is no surprise that Phoenix opposes their simple chronology, presenting archive work in Phoenix as a more temporally complicated and conflicted undertaking that resists the idea of a worked-through past. Here archive work returns as unfinished business. The film plays many years before the Frankfurt Auschwitz Trials, but with its closing dedication signals the work Bauer will undertake in triggering this watershed event. ${ }^{16}$ Phoenix tells the story of Nelly Lenz, a Jewish singer who survives Auschwitz, but on a death-march in the last days of the camp sustains gunshot wounds that damage her face beyond recognition. Following reconstructive surgery, she tries to find her husband, who, she subsequently and reluctantly learns, denounced her. He seems not to recognize her following her operation but sees that her similarity to Nelly (whom he believes dead) could help him claim her inheritance. In order to persuade his friends that this woman is his wife Johnny stages her homecoming. At the scene of this charade Nelly suggests a rendition of Kurt Weill's "Speak Low," the film's musical and the song she and Johnny used

\footnotetext{
${ }^{13}$ Eva Hoffmann, After Such Knowledge, 25, quoted in Gwyer, "Beyond Lateness?" 138.

${ }^{14}$ Eric Rentschler, The Uses and Abuses of Cinema, 320.

${ }^{15}$ Fisher, Christian Petzold, 9-10.

16 Petzold's reference to "dem Dokumentarfilm 'Fritz Bauer'” suggests he is familiar with Ziok's 2010 documentary Fritz Bauer. Tod auf Raten (Westphal, "Ich wollte kein Guido-Knopp-TV." Petzold has also explained that Phoenix is in dialogue with Alexander Kluge's "Ein Liebesversuch." Published in 1962 and drawing on an account of an experiment carried out in Auschwitz, an account used already in the Nuremburg Trials, the prose text belongs "zeitgeschichtlich in die unmittelbare Vorgeschichte der Auschwitzprozesse" (Schulte, “Alexander Kluge. 'Ein Liebesversuch””).
} 
to perform together before she was deported. As he accompanies her on the piano, however, Johnny sees the prisoner tattoo on Nelly's arm and he must recognize her as the wife he betrayed and who has survived Auschwitz.

The film begins as Nelly is brought back to Berlin by her friend Lene, her face swathed in blood-soaked bandages. However, as the director explains repeatedly in interviews, the opening scene was supposed to show something different: the first day's filming was spent recreating an archive image from the Shoah Foundation, which shows a death-march from Auschwitz in the last days of the camp, that is, the scenario in which Nelly sustains her disfiguring injuries. Petzold explains that what appeared to be a beautiful color image of a forest bathed in impressionistic dawn light, on second glance, revealed bodies lying on the ground, camp inmates who had been shot by the uniformed figures also in frame. ${ }^{17}$ The director wanted to recreate this scene, but on filming realized that this was a mistake: he had produced the same kind of clichéd footage that dominates "all the other Holocaust movies," and broken the injunction on Holocaust images, which, he realized, exists for good reason. ${ }^{18}$ Petzold believed a reconstruction of the photograph was necessary to understand "wo sie [Nelly, the survivor] herkommt" ("where she came from"), namely, from Auschwitz, ${ }^{19}$ but discovered that the archive image permitted only a re-presentation or remediatization that reinscribed and even increased the distance between his film and the traumatic event at its origin. Petzold abandoned the footage produced on this first day of filming and began instead with Lene explaining what the reconstruction was supposed to show, namely, that Nelly "comes from the camps."

\footnotetext{
${ }^{17}$ See, for example, Steinhoff, "Ich mag keine Nazis ins Bild setzen"; Petzold also makes this the premise of his "Director's Statement," in the press kit. Petzold's source might seem surprising as the Shoah Foundation is a repository of video survivor testimony and not a still image collection. Images can be found within the testimonies, however: interviewees are asked at the end of each interview if they would like to show any photographs and these are also catalogued and made part of the searchable database like the spoken contents of the interview. I am grateful to Martha Stroud at USC Shoah Foundation for her introduction to the database.

18 Young, "The Past is Not Myself," 40.

${ }^{19}$ Suchsland, "Es war nicht so, dass wir richtig wussten, was wir da tun."
} 
The director's attempt at archive work exposed what Jacques Derrida in Archive Fever describes as the gap between the event and its trace. ${ }^{20}$ The archive image is haunted from the beginning by its iterability: it is reproducible, but as such and as a consequence only comes in the place of the singular - and, here, traumatic - event. Moreover, Petzold's work with the archive showed him that the images that remain as traces of traumatic events cannot simply be made to stand in for what has been lost: "Ich konnte dem Ausgelöschten nicht einfach ein Bild geben und so tun, als wäre alles möglich!" (“I couldn’t just replace what had been erased with an image and pretend that anything is possible!" ${ }^{21}$ With this realization the director gestures towards the feverish archival desire - Derrida's mal d'archive - which runs counter to the recuperative version of archive work that preserves traces of the past (work undertaken emblematically by Bauer in the process of "Aufarbeitung") to overwrite the gap between traumatic events and their traces through acts of representation and to repress the repetition of violence implied in such acts. With his rejected archival opening and closing dedication to Bauer Petzold frames Phoenix through the unfinished business of archive work. ${ }^{22}$ Moreover, by reversing the chronology of these parenthetical references (putting his own archive work before Bauer's) he underscores the contradictory temporality of the posttraumatic archive.

Phoenix echoes the refrain of Weill's "Speak Low," to show how, in the immediate postwar period, the traces of trauma emerge "too soon" to be properly acknowledged as a

\footnotetext{
${ }^{20}$ Derrida, Archive Fever, 98-100.

${ }^{21}$ Westphal, "Ich wollte kein Guido-Knopp-TV." Petzold describes this restriction as moral, rather than aesthetic, but it should perhaps be understood in terms of what Buhanan describes as the "image-ethics" at stake in his films (see Buhanan, "What's Wrong with this Picture?"). Petzold's attempted reconstruction for Phoenix might reveal the influence of Harun Farocki, with whom Petzold wrote the screenplay for Phoenix. In Bilder der Welt und Inschrift des Krieges (1988), Farocki considers what it means to see something initially overlooked upon closer, later inspection. Petzold evokes the same language in his description of the death-march image, which appears almost pastoral, idyllic, until, upon second glance, the corpses on the ground become visible. In reconstructing this image, Petzold wanted to illicit this same response of taking another look to see what was really there (See Nayman, "The Face of Another: Christian Petzold's Phoenix").

22 Petzold's fundamental concern with the trope of work is discussed by Andrew J. Webber in “'Good Work': Speed, Slowness and Taking Care in Christian Petzold's Barbara” and Screening Work, a forthcoming monograph co-authored with Stephan Hilpert.
} 
crucial resource for working through. Meanwhile, Petzold, as part of a later generation - what Hirsch calls the "generation of postmemory" 23 is dependent on such traces, but comes too late to this project to be able to use the material that remains to him (here, the Shoah Foundation photograph) without reproducing the shortcomings of other films in their mediatization and re-mediatization of Holocaust images. Moreover, this condition of belatedness affects Petzold's narration, at a later stage, of earlier events: Phoenix is a film about the time before the Frankfurt Auschwitz Trials, but made in a time after, cannot help but stumble over Bauer's archive work and its effects on the trajectory of "Aufarbeitung."24 Petzold's insistence on telling the story of Phoenix's abandoned opening shows how archive work, seen from the dual perspective of prematurity and belatedness, is fundamental to his film, and raises ethical and political questions about the use of archive material in engaging with this period of history: how was this material produced and how did it come to remain? What does it show and what does it obscure? Playing in the days and weeks after the war Phoenix traces the emergence of the kind of material needed by Bauer to initiate the process of "Aufarbeitung," that is, the emergence of the Holocaust archive. But in positioning his own attempted reconstruction of this archive at the beginning of the film Petzold also thematizes the post-Holocaust archive. Indeed, by predicating the emergence of his film on this failure Petzold emphasizes the difficulty but inescapability of encountering the Holocaust archive from a contemporary perspective through the lens of cinema's remediatization of Holocaust imagery (what Petzold calls "all the other Holocaust movies").

\footnotetext{
${ }^{23}$ Hirsch, The Generation of Postmemory. In her work, Hirsch refers to the second generation, but scholars have since used her concept of postmemory to refer in an extended sense to those generations that did not directly experience past events.

${ }^{24}$ In this sense, Phoenix shares Petzold's long-standing concern with what Jaimey Fisher has called "the burdens of afterness" ("Petzold's Phoenix, Fassbinder's Maria Braun, and the Melodramatic Archaeology of the Rubble Past"). According to Fisher Petzold's concern for history has enabled his return to previous modes of cinema, performed as a Benjaminian "archaeology of genre," in order to refunction them for his "aesthetic and political" purposes (Fisher, Christian Petzold, 15). Fisher and Wim Staat have shown how Phoenix similarly returns to the genres of earlier cinema - the melodrama, the rubble film (as well as its remaking by Fassbinder) - in a continuation of Petzold's project (Fisher, "Petzold's Phoenix, Fassbinder's Maria Braun" and Staat, "Christian Petzold's Meoldramas").
} 
In what follows I show how in Phoenix Petzold thematizes the precarious emergence of the Holocaust archive though the intradiegetic performance of archive work in order to foreground and contextualize the challenges of working with the post-Holocaust archive (his own extradiegetic archive work): in trying to re-present Germany's traumatic past belatedly he sees the risk of overwriting the very experiences he seeks to memorialize. While Lene anticipates the archive work of figures like Fritz Bauer in her attempts to gather and preserve, in recuperative mode, the traces of loss and destruction, Johnny works in feverish archival mode (after Derrida), repressing and obliterating these traces. In his attempts to recreate a version of his wife that precedes her traumatization he disavows and even erases her experiences in the camps and thus her identity as survivor. Petzold's film shows how what remains to subsequent generations for their (belated) understanding of the Holocaust is inflected by the contradictory modes of archive work performed (prematurely) by both protagonists. Read in this way the diegetic concerns of Phoenix at once reiterate and anticipate Petzold's concern with his abandoned opening: the contemporary dependency of the generation of postmemory on images (in their reproducibility) threatens to disavow or erase the traumatic events of which they are (only ever and always already) a trace.

\section{Reconstruction's Archive Specters}

Nelly's facial injury and subsequent reconstruction (as other to herself) is the central device of Phoenix and is used to symbolize both the irreparable loss suffered by Nelly and others in the camps, as well as the desire for (future-oriented) reconstruction - and thus repression - in postwar Germany. Indeed, the labor of reconstruction is pivotal to Petzold's film, but it is a deeply ambivalent gesture: reconstruction (as "Wiederaufbau") in fact seeks to overwrite or even erase the traces of the past in order to forget. Nelly's reconstruction is not about the therapeutic restoration of the traumatized survivor: it is about the reconstruction of a version 
of the survivor, who, in showing no signs of her traumatization, facilitates the reconstruction of postwar Germany in amnesic mode. As Petzold remarks, the film's title refers not to Nelly, the survivor risen from the ashes of Auschwitz, but rather to West Germany and its economic success following the Second World War and the Holocaust. This is seen most troublingly in Johnny who reconstructs his wife, staging a homecoming that studiously disavows and even overwrites any traces of the ordeal from which she is supposed to return in order to profit from her inheritance. ${ }^{25}$

Nelly's appearance (both her physical "look" and her presence) presents an unwelcome obstruction to this collective process. The surgical reconstruction of her face, however, does away with this obstruction, allowing the forgetting of the past in order to begin anew. In his consultation with Nelly Dr. Bongartz prescribes a new identity for a new era, claiming that it can be advantageous to have "ein anderes Gesicht" ("a different face"). Nelly rejects his suggestion, insisting that she would like to be like her old self again, but her request can only be fulfilled in approximate and superficial terms. Following surgery, Johnny claims not to recognize her, only her similarity to his wife, which means that Nelly also sees her (old) self erased. As Petzold explains, "er erkennt sie nicht. Und sie erkennt sich selbst nicht. Weil man sich nur im Blick des anderen erkennt" ("he doesn't recognize her. And she doesn't recognize herself. Because you only recognize yourself in the gaze of the other"). ${ }^{26}$ So while Nelly agrees to Johnny's plan because she is desperate to be recognized as herself, her reconstruction in Johnny's hands necessarily means the erasure of her former self and thus her experiences in the camp: "Es ist ihr Ziel, und andererseits ist das der Horror für sie: Weil der Moment, in dem sie für die anderen auf diese Weise ... rekonstruiert ist, all das, was sie erlebt hat auslöscht" (It's what she wants to achieve, but on the other hand, it's a nightmare: Because in the instant that she's reconstructed for the others in this way

\footnotetext{
${ }^{25}$ Young, "The Past is Not Myself," 41. In a more literal sense, the title is a reference to the book on which the film is based, Hubert Monteilhet's Le Retour des cendres (1961).

${ }^{26}$ Peter Osteried, "Interview mit Christian Petzold über Phoenix."
} 
everything that she's experienced is erased"). ${ }^{27}$ Petzold's description of Nelly's dilemma recalls, even mirrors, his own concerns with his attempted reconstruction of a Holocaust archive image. The director realizes that he cannot simply produce an image to show what has been lost ("dem Ausgelöschten nicht einfach ein Bild geben") because this would overwrite the trauma he is trying to evoke and give representational space to in his film. ${ }^{28}$

Although Petzold abandoned his opening scene, he did include some material from the first day's filming in the final cut. ${ }^{29}$ This relates to an imagined scene, however, which is to say, Petzold extrapolates (temporally and geographically) from what is depicted in the archive image. Under anesthetic for her reconstructive surgery Nelly dreams (or fantasizes) her return from the camp. ${ }^{30} \mathrm{~A}$ female figure wearing striped prisoner clothes walks through the sun and the rain towards the boathouse, where Nelly had been hiding before her arrest. Nelly's dream wants to function as wish-fulfilment (and stages precisely the scenario that is denied to her in reality): Johnny has been waiting for her and she calls his name, anticipating that he will turn around and recognize her. This wants to be a scene of recognition, which, unlike the version staged later by Johnny, does not necessitate the overwriting of her experiences. It is unclear whether Nelly's wish is fulfilled in her dream, however, since the sequence cuts abruptly to Nelly recuperating from the surgery. Moreover, the dream itself resists recognition: the female figure is shown first from behind and then with the face obscured by shadow (there is in fact little to indicate that this is Nina Hoss); facing the piano, Johnny's back is all that is visible to the camera (this figure is, by contrast, unmistakably Ronald Zehrfeld). In this sense, then, Nelly's dream under anesthetic marks the impossibility of recognition and functions not as wish fulfilment, but as a premonition. Of course, what has

\footnotetext{
${ }^{27}$ Interview with Petzold, press kit, n.pag.

${ }^{28}$ Westphal, "Ich wollte kein Guido-Knopp-TV."

${ }^{29}$ Young, "The Past is Not Myself," 40.

${ }^{30}$ Olivia Landry argues that it "appears to mediate the subjective memory of Nelly," but Petzold calls this a "dream sequence" and, given the film's opening, which shows Nelly's return, it does not seem possible that this could be anything other than a fantasy ("A Body Without a Face," 199; Young, "The Past is Not Myself," 40).
} 
been happening while Nelly dreams this fantasy of recognition is the reconstructive surgical procedure carried out in the mode of postwar reconstruction, which is to say, building or writing over the destruction left by violence. It is this procedure that makes her (apparently) unrecognizable to Johnny, allowing him to carry out his manipulative scheme. Before she loses consciousness, Bongartz encourages his anaesthetized patient to count backwards. Counting backwards suggests turning back time, and perhaps triggers Nelly's fantasy flashback where she dreams of the homecoming that she had desired for so long. But led by Bongartz, counting down to zero also leads Nelly towards "Stunde Null," the zero hour from which West Germany will reconstruct itself anew. Performed here symbolically, metonymically even, in Bongartz's surgical reconstruction, the procedure will render Nelly's fantasy of recognition - of being recognized as herself, following her experiences impossible.

After the operation, Nelly leaves her bed and follows a fellow patient (one of several doppelganger figures in the film) to the surgeon's office, where she discovers the accoutrements used in the service of each patient's reconstruction - surgical diagrams, plaster casts, and personal photographs of patients from a time before their disfigurement. Under her name Nelly finds two such images, which Lene has given to the doctor to aid surgery: through the mournful scrutiny of a lost object glimpsed in the memento mori of the photographic image Nelly sees herself and sees that this person is lost to her forever. She may have survived, but she exists now only as reconstruction, a copy made from a photographic reproduction: in this sense Bongartz's surgery has functioned to do precisely what Petzold did not want to do with the film's opening, namely, “dem Ausgelöschten ... einfach ein Bild geben." 31 This scene of close scrutiny of a photographic image is followed by another as Petzold cuts from the hospital to an image of Lene working at a desk. Using a magnifying

\footnotetext{
${ }^{31}$ Westphal, "Ich wollte kein Guido-Knopp-TV."
} 
glass she scours grainy photographs taken at the camps, searching for prisoner numbers tattooed on corpses and scribbling her results on a piece of paper. The photograph provides her with only half her information, however, and she cross references the numbers with a list contained in one of several singed files marked "Häftlinge" ("prisoners"). One column is filled predominantly with the word "Jude" ("Jew") and one, to the left, with the last three digits of a longer number concealed by the fold of the preceding page. Lene's finger moves across the line from the number to the name: the dead body is that of Esther Blum, Lene and Nelly's missing friend. With the cut from Nelly's realization of the irrecuperable loss of her own identity to Lene's scene of post-mortem identification Petzold underscores Nelly's status as survivor and ghost.

Lene's work of identifying the dead, of reconstructing the identity of those who perished in the camps, is a counter-movement to the gestures of postwar reconstruction ("Wiederaufbau") that seek to overwrite the traumas of the past. Lene's reconstruction aims to piece together the traces of the past in order to decipher what (or, more accurately, who) has been lost. It is staged as a kind of archive work, ${ }^{32}$ and, as a lawyer recently returned from exile, Lene could be seen to prefigure Bauer and the role he takes on in postwar Germany. ${ }^{33}$ She works for the Jewish Agency, helping those who have survived to start a new life in Palestine, but also identifying the dead. She has an acute sense of the injustice done to Jewish communities and individuals under the Nazi regime and seeks to bring those responsible to justice. However, her work is done too soon. Lene is frustrated by the will to forgive palpable among the remaining Jewish community and by what the film seeks to highlight more generally, namely, the unswerving collective drive to reconstruct Germany as if nothing had

\footnotetext{
${ }^{32}$ Landry describes Lene's work as "index[ing] the dead" (“A Body Without a Face,” 202). I am grateful to Michael Berkowitz for alerting me to the fact that there is no evidence that such procedures were used in identifying the dead. If this is a likely historical inaccuracy and thus a fictional conceit, it emphasizes Petzold's concern with questions of the archive and, specifically, the archive after Auschwitz.

${ }^{33}$ She also takes her own life as Bauer is supposed to have done, and, in her androgynous style and intimate relation to Nelly, she might be seen as a queer figure, echoing Bauer's homosexuality.
} 
happened. Her attempts to begin the kind of work Bauer will undertake are made before people are willing or able to confront the past, but her efforts also stall prematurely because, feeling closer to the dead than the living, Lene commits suicide. Her short life is over too soon.

Lene's archive work is undertaken prematurely, but it already exposes the complicated status of the traces that remain. Identification must take place remotely, belatedly, and, moreover, supported by the same bureaucratic apparatus designed and implemented in the administration of a dehumanized workforce and the fabrication of corpses. As the singed edges of the prisoner file show it is a matter of chance that the dead can be identified at all: upon defeat and in the hands of the enemy, the file that was produced in the efficient administration of the regime represents a threat to its representatives and is therefore to be destroyed (as many camp documents were when the liberating forces approached). And yet it remains, hardly a phoenix, but retrieved from the ashes in spite of all, and used now in Lene's vital, but for many unwanted work. Lene's use of the photograph and file in this sequence highlights how the Holocaust archive is a necessary, but also a "troubled and ... troubling" resource, to quote Derrida. ${ }^{34}$ Esther can only be identified via the bureaucratic system (that marks her) as a camp prisoner. Identification does not reinstate her (prewar) human identity; rather, dependent on the number to which she had been reduced, it reinforces her dehumanization. The file is even reflected in Lene's glasses, showing how she can now only see her friend in, and as an entry on, this list, despite her efforts to pay her the last respect of identification.

The photograph Nelly takes down from the wall of the surgeon's office will also come to be marked with the signs of Lene's archive work. It is a photograph showing a group of women, whose relaxed, open, and carefree posture indicates that they are friends enjoying life

\footnotetext{
${ }^{34}$ Derrida, Archive Fever, 90.
} 
before political divisions and war change their world forever. Lene and Nelly form the center of a group of four women, who are flanked by two others to their left. The faces of these two women are now marked by circles, which, Lene tells Nelly, signify that these friends are Nazis. The woman to their right (seated to the left of Lene) bears a cross above her head: she has died and, when Nelly shows Lene the photograph, Lene says laconically, that a cross must now also be added above Esther, the figure at the far right of the group. This image has been used in the service of (surgical) reconstruction, which, in an extended sense, facilitates the disavowal or overwriting of destruction, but it also bears the marks of the losses that this reconstruction tries to cover over, which means that, for these women, who cannot simply forget, in the aftermath of war, the prewar image is seen differently.

Formally an innocuous image of youth and friendship, it now shows the division of this group into victims and those implicated in their fate, if not as perpetrators, then as bystanders. When Nelly shows Lene this image she also uses it to note this irreparable fissure between her past and present. She has asked her friend to drive her to the bombed-out site of her former home in the hope of finding a trace of her husband, Johnny. As she moves unsteadily over the rubble she catches a glimpse of herself in two shards of a mirror and is shocked by her face, which is still bruised from the surgery and different from her own. This division is symbolized through the divided and doubled reflection: the two shards show two partial images. Shaken, Nelly returns to the car and takes out the photograph from her pocket, using this now precious index of her former self to remind herself of her own appearance, but also to confirm the feeling of profound alienation she has just experienced. She turns to Lene and asks if her friend would recognize her. Despite Lene's reassurance, Nelly shakes her head, and pointing to the photograph, says that this image, not the person sitting in the car, is who she is: "Das bin ich" ("That's me"). We see how Nelly now only exists as a copy of an image and how Bongartz's archive work has paved the way for Johnny's. 
In this scene the group photograph now has an additional cross over one of the figures, not Esther - Lene has yet to break the news to Nelly - but over Nelly. This second cross was not there in Bongartz's office and is either an intra- or extra-diegetic addition; a mark made by Nelly as a kind of memorial to her lost self, or Petzold's deliberate break in continuity to remind us of precisely this loss, or perhaps both. This second cross is lighter, ghostly even, signaling Nelly's status as specter, a survivor not properly recognized and dead to herself. Of course, there must ultimately be four crosses on the photograph: the cross Lene will add to Esther and that to be added above her own head once she has taken her own life. Although this photograph is ostensibly used for the purposes of (surgical) reconstruction, it in fact comes to mark the erasure of four identities. Petzold's sequencing means that Nelly's contemplation of this image - first in Bongartz's office, then in Lene's car - frames the scene of Lene's archive work with the image of tattooed corpses. Lene's use of the material from the camps shows the emergence of the Holocaust archive that will come to be used in working through National Socialism (legally, historically, and culturally), but this process also indicates how the Holocaust changes the status of material traces more fundamentally: the group photo of a time before now also forms part of the material memory marked by the fact of persecution and annihilation - it marks the rupture of the Holocaust in the lives of these women and can only be viewed in the shadow of this event that came after its making.

In the same place that Lene tries to piece together the traces that remain from the camps Johnny attempts to do away with the evidence of his culpability. Following her discovery among the files and documents, Lene leaves her desk to mourn her friend briefly and discretely. In the corridor she witnesses an American colleague calling after Johnny who has just ransacked a stack of index cards in an attempt to purloin the record of his divorce from Nelly. Filed under the Nazi "Blutschutzgesetz" shortly before her arrest, it now serves as evidence of his betrayal. This scene is particularly significant because it indicates that 
Johnny already intended to claim Nelly's inheritance before he encounters her at the Phoenix club. At this stage he will presumably make his claim as a widow and thus needs to destroy the evidence that he had in fact already invalidated their marriage. That he subsequently encounters a woman who could pass as Nelly makes his claim (staged as her claim) more straightforward, even if he will have to give her a cut of the profits. The scene shows that, acting alone or with a partner, Johnny needs a blank slate on which to recreate the fantasy image of his wife before he betrayed her and before her deportation to the camps. Nelly obliges and offers herself to him as tabula rasa as she sees that she can only maintain contact with him by playing along with his game. When Johnny asks her name, she replies "Esther." She knows that, as a result of Esther's archive work, there is evidence that Esther is dead, but she also knows that those around her do not want to be confronted with this evidence. Thus, she chooses the name Esther not in an act of remembrance for her dead friend - it is too soon for such a gesture - but because it is an empty signifier and thus offers the canvas upon which Johnny can project his fantasy version of her. Esther is a figure of disavowed trauma and only through her can Nelly begin to perform the part of "Nelly," the erased, silenced version of herself that Johnny wants to see.

\section{The Archive Fantasy of Reconstruction}

Johnny's obsessive attempts at creating a fantasy version of Nelly, at bringing to life a woman he believes dead, signal Petzold's debt to Vertigo (1958) and Hitchcock's reworking of the Pygmalion myth. Using the image traces of one woman to create another (image), these male fantasies can be seen, alongside Wilhelm Jensen's "Pompeian Fantasy," Gradiva (1903) as archival - or, more accurately, "patriarchival," - fantasies. ${ }^{35}$ Jensen's archaeologist

\footnotetext{
${ }^{35}$ Nicholas Rand and Maria Torok argue that Jensen's novella is a reworking of the Pygmalion myth in "A Case Study in Literary Psychoanalysis: Jensen's Gradiva." See also Hite, "Bas-Relief: Footnotes on Statue-Love and Other Queer Couplings in Freud's Reading of Gradiva." In addition, Weill's "Speak Low" featured in the
} 
protagonist, Norbert Hanold, searches for the real woman whose image he has encountered in a bas relief and finds her in the form of his childhood friend, Zoe Bertgang. In his analysis of the story Freud famously diagnoses Hanold's repression of his sexual desires and shows how the work of archaeology offers an analogy for the psychoanalytic work of uncovering repressed desires. ${ }^{36}$ In Archive Fever Derrida returns to Jensen's novella and Freud's analysis to show how the figure of Gradiva is at once the manifestation and frustration of an archival fantasy, that is, the desire to return to and possess an original object. As copy or trace Gradiva is reproducible, but, as such, she comes in the place of, which is to say, traces over, an original. According to Derrida the iterability of the trace defines the archive, but it also indicates how the archive does not simply preserve the traces of past events, it also serves to overwrite them: "the repetition compulsion, remains ... indissociable from the death drive. And thus from destruction. Consequence: right on that which permits and conditions archivization, we will never find anything other than that which exposes to destruction." 37 The destructive impulse that emerges with the very possibility, or as the condition of the archive produces archive fever. The archive, however, represses its own destructive drive, meaning that, for Derrida, "repression is an archivization." Repression is "to archive otherwise, to repress the archive while archiving repression." 38

In his archival fantasy of reproducing a version of Nelly that existed before her deportation Johnny overwrites the traces of the traumatized woman he encounters but represses the violence he does to her (in a way that, moreover, performs and repeats his repression of his guilt following his betrayal of Nelly). By reproducing an image of Nelly from a time before he deliberately ensures that the real Nelly cannot return. In other words,

Pygmalion musical, One Touch of Venus, which premiered in 1943 and was made into a film in 1948 starring Ava Gardner. Derrida writes of the "patriarchive" in Archive Fever, 4; 36.

${ }^{36}$ Freud, Der Wahn und die Träume in W. Jensens "Gradiva."

${ }^{37}$ Derrida, Archive Fever, 12

${ }^{38}$ Ibid., 64. See also Orells, "Derrida's Impression of Gradiva: Archive Fever and Antiquity." 
Johnny exploits the logic of the archive which "forbid[s] the return to the origin." ${ }^{39}$ The unscrupulous actions of Petzold's protagonist serve to highlight the director's dilemma faced with his own archive reproduction. In attempting to reconstruct the scene shown in the Shoah Foundation image Petzold reproduced a copy and found himself at even more of a remove from the event he was trying to engage with. He saw how such a reconstruction simply repeats the reproduction of such images attempted by filmmakers before him and in fact obscures what is at stake. To have kept and shown this footage would have been to repress the archival violence at the origin of his film. Instead Petzold tries to thematize the destructive and repressive aspect of the archive, both in talking about his film and through his protagonists. Indeed, Johnny's repression of his own destructive actions (betraying Nelly and then overwriting her survivor identity through the reconstruction of a fantasy version) is itself a kind of archivization, following Derrida, and Petzold seeks to unearth the traces he has left in order to show how the archive work left to subsequent generations must also include retrieving the traces others sought to conceal (here, in the mode of disavowing the traumas of others).$^{40}$

Driven by a kind of archive fever, Johnny creates his version of Nelly as an archival figure, who is made to perform the erasure of her survivor self through the reiteration of the traces that precede her traumatic experiences (and thus overwriting these traumatic traces). Johnny's obsession with the image of a (putatively) dead woman replays the desperate search of Scottie (John) Ferguson in Vertigo for Madeleine and of Norbert Hanold for the woman he calls Gradiva. Like Jensen's protagonist, Johnny also fixates on the gait of his fantasy woman as a key indicator of her ability to pass as Nelly. He tells her to practice walking in a pair of Nelly's shoes, becoming impatient when she does not walk as Nelly did. Johnny needs this

\footnotetext{
${ }^{39}$ Derrida, Archive Fever, 92.

${ }^{40}$ Petzold describes Johnny's feverish archival work of reconstruction and destruction in the terms of psychoanalysis: "The thing that I'm interested in is Pygmalion: a man is creating a woman - and you know from Sigmund Freud, in traumatic situations you recognise, repeat and erase. ... And this is the work of Johnny" (Young, "The Past is Not Myself," 41).
} 
woman to pass as Nelly, and in a literal sense, to be able to walk as she did, not only so that others will believe their game, but also so that this woman can pass over or bypass Nelly's traumatic experiences in the camps. For Petzold's audience, however, the focus on shoes is a reminder of Auschwitz: the distinctive gait produced by the distinctive shoes contrast with the loss of individuality in the camps, symbolized in the piles of discarded possessions and most iconically in the anonymous mass of shoes now seen behind glass at the museum that occupies the site of the former camp. During their rehearsal Nelly tries to protest, saying that no one will believe their performance of homecoming if she returns from a concentration camp wearing elegant shoes from Paris, but Johnny disagrees - this is precisely what people want to see: "Sie wollen Nelly sehen und keine zerstörte Lagerinsasse. Daran arbeiten wir hier" (“They want to see Nelly, not some disturbed camp in mate. That's what we're working on.” Emphasis mine). Johnny's version of archive work, his recreation of a version of Nelly using the material traces from a time before, studiously bypasses her experiences in the camps, insisting on an image that precedes this trauma. Recreating a version of Nelly that can no longer exist, Johnny overwrites Nelly's posttraumatic identity with an archival fantasy.

It is not only Nelly's gait that Johnny focuses on in preparing the staged homecoming. He also insists that Nelly dye her hair and apply makeup, using an image of film star Heddy Lamarr, who, he tells her Nelly, served as a model for all of their performances. As Petzold notes, at this stage, Nelly "play[s] this game with him because she wants to be recreated. She loves his memories and wants to be recreated."41 Faced with the familiar image of Lamarr's face and the fantasy world she provided access to, Nelly caresses this image with the same longing with which she touched the group photograph of her together with her girlfriends. If re-enacting her earlier performances is the only way in which she can get Johnny to acknowledge her, she seems willing to do so. His use of this picture shows how Nelly was

\footnotetext{
${ }^{41}$ Kasman, "Filming around the Wound."
} 
always already a copy of an image so his procedure of recreation or reconstruction can easily be replicated with what he believes to be another woman. The intradiegetic reference to cinema and media simulacra, moreover, indicates Petzold's concern with the implications of representation. Johnny's feverish reproductions of fantasy images overwrite Nelly's real identity and her experiences; in doing what Petzold comes to understand to be impossible, namely "dem Ausgelöschten ... ein Bild geben," ${ }^{2}$ Johnny exposes the danger of archival fantasies that make a fetish object of the image and in so doing obscure the event of which it serves as a trace.

Johnny's desire to erase or silence the traces of Nelly's experience the camps also echoes Petzold's concern for the consequences of his belated archive work in a further aspect of the couple's rehearsals for Nelly's staged homecoming. Although Johnny has told her that they are working on the re-production of Nelly "und keine zerstörte Lagerinsasse" ("daran arbeiten wir hier"), Nelly cannot believe that no one will ask her about her experiences and wonders what she should say. An irritable Johnny asks her what exactly she would want to recount ("erzählen"). What follows is based on a survivor testimony found in the Shoah Foundation's video archive, and in this sense, seems to represent the archival reconstruction that Petzold rejected for his film's opening. ${ }^{43}$ However, Nelly never finishes her sentences. Her halting, fragmented speech on the one hand reflects the difficulties of survivors to find the words to communicate their experiences, something that Petzold noticed when listening to testimonies in preparation for the film. On the other, it indicates a refusal to simply recreate this material to create narrative. The fact that Nelly's speech breaks down draws attention to the gaps and ruptures produced not only by her experience in the camps, but which emerge subsequently as these experiences are rejected by those to whom she returns. For Johnny, her words are not testimony, rather they belong to the realm of narrative and

\footnotetext{
${ }^{42}$ Westphal, "Ich wollte kein Guido-Knopp-TV."

${ }^{43}$ Press kit, n. pag.
} 
perhaps even fiction - he uses only the verb "erzählen" and when he asks her where she has got these stories from she feels compelled to say that she read them somewhere. He seems to invite her to share her words with their friends: "Dann erzählen Sie...." (“Well tell them...”). But he in fact mocks her: “...Wenn Sie danach gefragt werden” (“...If anyone asks you about it"). By limiting her attempt to testify to the concealed space of their rehearsals, Johnny effectively silences her, ensuring that she will not attempt to repeat her words during the performance of her homecoming.

Phoenix is dedicated to the man who will initiate the legal process by which such testimony is gathered and used in judicial proceedings, but, used before witnesses are able to formulate statements and when no one is prepared to listen, this is spoken "too soon." Nina Hoss's halting and stumbling delivery emphasizes the temporal distance between the experience, its aftermath and the often belated time of testimony. The accounts given at the Frankfurt Auschwitz Trials and later as part of the work of making testimony archives cannot be made to function retroactively, to be spoken sooner than they were. Their very latency ("Nachträglichkeit") is what makes these traumatic narratives. Used "too late," however, that is, in verbatim reenactments, they threaten to become pathos-laden clichés. Crucially, Petzold not only stages the premature attempt at testimony, he also shows how resistance to such attempts (Johnny's impatience and incredulity). If he had simply had Nina Hoss read out the testimony from the archive it would have overwritten the unwillingness of postwar society to acknowledge the suffering of survivors which prevented attempts to give such accounts being made sooner.

\section{The Return of Traumatic Traces}

Although Johnny is sure that no one will want to ask Nelly about her experiences in the camp, he also knows that their friends will want to see the prisoner tattoo that they have heard 
about. Where all other evidence (notably personal accounts) is dismissed or disbelieved, the tattoo is, perversely, the only marker of credibility, the only sign that will convince the general population otherwise unwilling to engage with Nazi crimes of the existence of the camps and camp inmates. The status of the prisoner tattoo is perverse because it suggests that people such as Johnny still only trust the authority of the regime to provide evidence of experiences that expose its tyranny. Still functioning as what Nicholas Chare calls a "sign of surety for National Socialism's authority,"44 it suggests a residual belief in the regime after its defeat, a conviction that resists believing the stories of those who would discredit it. Johnny anticipates their peers' morbid fascination with the authenticating sign of Nelly's survivor status, with the evidence of an otherwise unbelievable story. But since this woman "Esther," who plays Nelly - is not (Johnny seems to assume) a camp survivor, she would not have this mark, and so he needs to make a mark that will account for this absence. He wants to brand Nelly so that she can tell the assembled crowd who come to welcome her home that she has tried to remove the tattoo (in order to erase this traumatic or even shameful identity). This aspect of the film might otherwise be read as an indicator that Johnny does not really believe that this is not Nelly and so needs to erase this sign to ease his guilty conscience. Either way, the mark he intends to make constitutes an act of erasure, real or imagined, that seeks to do away with the evidence of Nelly's having been in Auschwitz. ${ }^{45}$

This is the final, most radical instance of Johnny working to repress the recent past by erasing - by overwriting - its evidence. The mark, borne by the dead and the survivors, is also the index of the Holocaust (both the sign that maintains a connection to that of which it

\footnotetext{
${ }^{44}$ Chare, Auschwitz and Afterimages, 93.

45 Johnny's intention and the image Petzold evokes recall the highly manipulative project 80064 (2005) by the Polish artist Artur Zmijewski, who films himself persuading a Holocaust survivor to have his tattoo "renewed" by a tattoo artist. This "renewal," however, threatens to overwrite the tattoo as well as the man's status as survivor. Instead, he is made the object of postmodern art and a pseudo-ironic comment on the iconicity of the Auschwitz tattoo in the twenty-first century. Incidentally, Zmijewski's project was supposed to be shown at the Fritz Bauer Institute as part of an exhibition to commemorate the fortieth anniversary of the Frankfurt Auschwitz Trials (see Kékesi, Agents of Liberation, 142-48).
} 
is a sign and the systematic list, the archive of camp inmates and, subsequently and unintentionally, of Holocaust survivors). According to Johnny's plan the sign would be erased through the infliction of a "kleine Wunde," a small wound or trauma to displace attention from the absence of the mark that would authenticate the unspoken and unspeakable trauma of the Holocaust. However, it also marks the limits of Johnny's ability to realize his archival fantasy of recreating a prewar image of Nelly. Indeed, Johnny's attempt to create an ersatz-wound is an important moment in the film's engagement with the question of archive work and marks a significant shift in Nelly's behavior: if, in her devotion to Johnny, she has submitted to all his demands, now she stands up for herself. She unwraps the pistol Lene has given her for self-protection as well as the copies of the divorce documents proving Johnny's betrayal that she left to Nelly in her suicide note. As Johnny wants to perform his most radical gesture of erasing the evidence, Nelly begins to understand the importance of documentary, archival evidence in testifying to her experiences and asserting her survivor identity. In this way, she finally takes up Lene's archive work. ${ }^{46}$

Johnny wants to make his "kleine Wunde" because he assumes Nelly is not a survivor, so when Nelly takes off her jacket and, during their performance of "Speak Low," reveals her prisoner tattoo, it appears where it should not. It produces shock and silence; the fragile fabric of his fabricated homecoming is ruptured. The red dress that Johnny tells her to wear in his quest to make her appear as Nelly the Auschwitz survivor reveals the tattoo that is the marker of her true identity as Nelly the Auschwitz survivor after all, but too soon. His frozen face signals this closing scene as one of slow, belated, but traumatic recognition of the extent of his damaging behavior and the truth of Nelly's earlier testimony heard falteringly and prematurely. This scene finally brings the recognition deferred throughout the narrative as a result of denial and disavowal. It might appear as a classic scene of anagnorisis, in that it

\footnotetext{
${ }^{46}$ If, as Landry argues, Nelly's choice of song is a dedication to her dead friend, Lene, it prefigures Petzold's dedication to Bauer (“A Body Without a Face," 202).
} 
brings knowledge, knowledge that also disrupts and disturbs social and narrative order. ${ }^{47}$ But the knowledge that is revealed in this moment exceeds the narrative conventions of the recognition scene. Moreover, unlike the conventional scene of anagnorisis, this does not produce analeptic narrative, that is, an explanation of where this mark came from. ${ }^{48}$ The room is lined with framed photographs, individual and groups portraits that want to provide the illusion of a continuity in social order. The composition of the re-assembled group of friends also seems to want to recreate the scene captured in the black-and-white image that Johnny gives Nelly to prepare for this meeting, but the sight of her tattoo exposes the failure of such an attempt, failure seen in the grotesque expressions on the friends' faces. The tattoo is the indelible mark of the trauma of the Holocaust and its significance cannot be overlooked or bypassed. Here, the archival trace does not appear as an image or document, but as a mark or stain on the field of vision. It marks the breaking off of narrative, echoed in the breaking off of Nelly's rendition of "Speak Low." The words that resound in the silence that follows are "I wait..." As Nelly turns and walks out of the room, the camera does not adjust its focus to follow her, and Petzold cuts from the figure of Nelly, once again beyond recognition, to his dedication. It is "too soon" for the recognition of the victims and their experiences and we must wait until such a time as the visual and textual traces will be read and the witnesses listened to, must wait until the archive work undertaken by Fritz Bauer.

\section{Conclusion}

In the immediate postwar phase that Phoenix thematizes the prisoner tattoo appears as a marker that has displaced or overwritten the prewar identity of the camp victims. We see how this is used to identify the dead via reference to the other remnants of the camp's own administration (Lene's archive work). It has not yet become a (sometimes pathos-laden)

\footnotetext{
${ }^{47}$ See Cave, Recognitions, 1-24.

${ }^{48}$ Ibid., 22.
} 
marker of camp experience and survival, which is to say, a kind of metonym for the Holocaust. In Petzold's scene of belated and traumatic recognition, it appears, moreover, as a distorting mark that indicates how the Holocaust archive cannot be properly assimilated into conventional archival logic of documents read for historical content and understanding. Where historical evidence includes the numbers used in the dehumanization and destruction of individuals, the very notion and the status of the archive is called into question. As Nicholas Chare reminds us, the tattoo is made by penetrating the surface of the skin, its ink is visible on the surface, but present below. As such, "the tattoo is untouchable," 49 and figures here as a reminder of the elusive, unknowable nature of the experience to which it testifies. Furthermore, the tattoo, which is seen "too soon" by Johnny and his friends but belatedly in this 2014 film, serves as a reminder that this index of the camps, the most immediate, most intimate evidence and material remnant of the Holocaust will soon disappear as the survivors into whose bodies it is inscribed pass away. The closing scene of Phoenix reminds us that the Holocaust archive will be available only in or as the shadow of the post-Holocaust archive. In this sense it foreshadows the film's abandoned opening scene - a reconstruction of the Holocaust archive, which can now only be seen in remediatized form.

Indeed, Phoenix is all too aware of its own belated status and Petzold draws attention to the difficult but necessary work with the traces that remain. Through the actions of Lene (identification of the victims) and Johnny (erasure of the traces that indicate his guilt), Petzold shows the gradual emergence of a precarious, fragile Holocaust archive that will, eventually, form the basis of Fritz Bauer's work, triggering the Frankfurt Auschwitz Trials and the gathering of testimony that will be so important to the long process of "working through" the past. Fritz Bauer's archive work, however, also signals the emergence of the post-Holocaust archive from the Holocaust archive, which is to say, the shifting function,

\footnotetext{
${ }^{49}$ Chare, Auschwitz and Afterimages, 101.
} 
role, or status of this material from documentation to material used in the remembering, commemoration, and memorialization of Auschwitz, as well as its aestheticization, consumption, and commercialization. As Johnny's reconstruction appears to the viewers as opportunistic sham that seeks to disavow Nelly's trauma through controlled staging, Petzold's own reconstruction could only have appeared as an attempt to overwrite what has been erased with the image that comes in its place ("dem Ausgelöschten ... ein Bild geben"). In thematizing archive work as an intra- and extradiegetic task, as a task performed both too soon and too late, as well as the task that remains, Petzold stages the particular problems of archive work after Auschwitz.

\section{References}

Abel, Marco. 2013. The Counter-Cinema of the Berlin School. Rochester, NY: Camden House, 2013.

Van Alphen, Ernst. 2014. Staging the Archive. Art and Photography in the Age of New

Media. London: Reaktion.

Assmann, Aleida. 2006. Der lange Schatten der Vergangenheit. Erinnerungskultur und Geschichtspolitik. Munich: Beck

—. 2010. "Canon and Archive.” In A Companion to Cultural Memory Studies, edited by Astrid Erll, Ansgar Nünning, 96-107. Berlin: de Gruyter.

—. 2013. Das neue Unbehagen an der Erinnerungskultur. Munich: C. H. Beck, 2013.

Buhanan, Kurt. 2016. "What's Wrong with this Picture? Image-Ethics in Petzold's Films." The German Quarterly 89, no. 4: 480-95. 
Burg, Susanne. 2014. "Ich hasse allegorische Filme.” Deutschlandradio Kultur. September

20. http://www.deutschlandradiokultur.de/christian-petzold-ich-hasse-allegorische-

filme.2168.de.html?dram:article id=298099.

Cave, Terence. 1990. Recognitions. A study in Poetics. Oxford: Oxford University Press.

Chare, Nicholas. 2011. Auschwitz and Afterimages. Abjection, Witnessing and

Representation. London, New York: I.B. Tauris.

Crownshaw, Richard. "Reconsidering Postmemory: Photography, the Archive, and Post-

Holocaust Memory in W.G. Sebald's Austerlitz.” Mosaic 37, no. 4: 215-36.

Derrida, Jacques. 1998. Archive Fever. A Freudian Impression, translated by Eric Prenowitz.

London and Chicago: University of Chicago Press.

Didi-Huberman, Georges. 2012. Images in Spite of All. Four Photographs from Auschwitz, translated by Shane B. Lillis. London and Chicago. University of Chicago Press.

Fisher, Jaimey. 2013. Christian Petzold. Urbana, IL: Illinois University Press.

—. 2017. "Petzold's Phoenix, Fassbinder's Maria Braun, and the Melodramatic

Archaeology of the Rubble Past." Senses of Cinema 84, September.

http://sensesofcinema.com/2017/christian-petzold-a-dossier/petzold-fassbinder/.

Freud, Sigmund. 1999. Der Wahn und die Träume in W. Jensens "Gradiva." In Gesammelte

Werke, vol. 7, edited by Anna Freud et al, 28-125. Frankfurt: Frankfurt am Main.

Gwyer, Kirsten. 2015. “Beyond Lateness? 'Postmemory’ and the Late(est) German-Language

Family Novel." New German Critique 42, no. 2: 137-53.

Hirsch, Marianne. 2012. The Generation of Postmemory. Writing and Visual Culture after the Holocaust. New York: Columbia University Press.

Hite, Christian. 2011. "Bas-Relief: Footnotes on Statue-Love and Other Queer Couplings in Freud's Reading of Gradiva." Postmodern Culture 21, no. 3.

https://muse.jhu.edu/article/475117. 
Hoffman, Eva. 2005. After Such Knowledge. A Meditation on the Aftermath of the Holocaust. London: Vintage.

Kasman, Daniel. 2015. "Filming around the Wound. A Conversation with Christian Petzold." Mubi. February 26. https://mubi.com/notebook/posts/filming-around-the-wound-aconversation-with-christian-petzold.

Kékesi, Zoltán. 2015. Agents of Liberation. Holocaust Memory in Contemporary Art and Documentary Film. Budapest and New York: Central European University Press.

Landry, Olivia. 2017. “A Body Without a Face. The Disorientation of Trauma in Phoenix (2014) and New Holocaust Cinema," Film-Philosophy 21, no. 2: 188-205.

Nayman, Adam. 2014. "The Face of Another: Christian Petzold's Phoenix." Cinema Scope 61. http://cinema-scope.com/features/face-another-christian-petzolds-phoenix/.

Petzold, Christian. “Director's Statement.” In Press Kit. N.pag. http://www.phoenix-derfilm.de/downloads/artwork-texte/PH Phoenix rgb.pdf

Popescu, Diana, and Tanja Schult, eds. 2015. Revisiting Holocaust Memory in the PostWitness Era. Basingstoke and New York: Palgrave Macmillan.

Orells, Daniel. 2010. “Derrida's Impression of Gradiva: Archive Fever and Antiquity.” In Derrida and Antiquity, edited by Miriam Leonard, 159-84. Oxford: Oxford University Press. Osborne, Dora. Forthcoming. What Remains: The Post-Holocaust Archive in German Memory Culture. Rochester, NY: Camden House.

Rand, Nicholas, and Maria Torok. 1997. “A Case Study in Literary Psychoanalysis: Jensen’s Gradiva." In Questions for Freud: The Secret History of Psychoanalysis, 54-73. Cambridge, MA: Harvard University Press.

Rentschler, Eric. 2015. The Uses and Abuses of Cinema. German Legacies from the Weimar Era to the Present. New York: Columbia University Press. 
Schulte, Christian. 2004, “Alexander Kluge. 'Ein Liebesversuch.” http://www.klugealexander.de/zur-person/texte-ueber/details/artikel/alexander-kluge-ein-liebesversuch.html. Staat, Wim. 2016. “Christian Petzold's Melodramas: From Unknown Woman to Reciprocal Unknownness in Phoenix, Wolfsburg and Barbara." Studies in European Cinema 13, no. 3: 185-99.

Steinhoff, Hannah. 2014. "Ich mag keine Nazis ins Bild setzen.” Planet Interview. 29 September 2014. http://www.planet-interview.de/interviews/christian-petzold/46231/. Steinke, Ronen. 2013. Fritz Bauer oder Auschwitz vor Gericht. Munich: Piper. Suchsland, Rüdiger. 2014. "Es war nicht so, dass wir richtig wussten, was wir da tun." Artechock. 25 September. http://www.artechock.de/film/text/interview/p/petzold_2014.html. Webber, Andrew J. 2016. “'Good Work': Speed, Slowness and Taking Care in Christian Petzold's Barbara." In Time in German Literature and Culture, 1900-2015, edited by Anne Fuchs and J.J. Long. Basingstoke: Palgrave. 173-88.

Webber, Andrew J. and Stephan. Forthcoming 2019. Screening Work: The Films of Christian Petzold. Oxford: Legenda.

Westphal, Anke. 2014. "Interview mit Christian Petzold über Phoenix: 'Ich wollte kein Guido-Knopp-TV."” Berliner Zeitung. September 8. http://www.berlinerzeitung.de/kultur/interview-mit-christian-petzold-ueber--phoenix---ich-wollte-kein-guidoknopp-tv--224750.

Wojak, Irmtrud. 2009. Fritz Bauer 1903-1968. Eine Biografie. Munich: Beck. Young, Neil. 2015. “The Past is Not Myself.” Sight \& Sound, June: 38-41. 